\title{
EFFECT OF DISTANCE FROM DRAIN LINE ON WHEAT CROP UNDER DIFFERENT RATES OF NITROGEN FERTILIZATION IN CLAY SOIL
}

Ramadam. S.A.; A.A.S. Gendy; N.I. Talha and A.A.El-Leithi Soils, Water and Enviro. Res. Inst., Agric. Res. Center, Giza, Egypt

\section{ABSTRACT}

This study was carried out to evaluate the influence of distance from drain line on response of wheat (Giza 168 variety) to different levels of $\mathrm{N}$-fertilizer. Two field experiments were conducted during 2003/2004 and 2004/2005 successive seasons. The experimental field provided with pipe drain network spaced at $20 \mathrm{~m}$. with $1.2 \mathrm{~m}$ depth. $\mathrm{N}$-fertilizer in the form of urea was added in three levels $(50,75$ and $100 \mathrm{~kg} \mathrm{~N} / \mathrm{fed}$.) at $\amalg / 4$ and $L / 2$ distance from drain line in two equal doses after the first and second irrigation, respectively.

Results showed that 1000 grain weight (gm), grain yield (ardab/fed.) and straw yield (Heml/fed.) significantly increased as the distance from drain line decreased from $L / 2$ to $L / 4$ in both studied seasons. These increases were equivalent to 1.37 and 1.16 (gm), 1.43 and 1.89 (ardab/fed.) and 1.69 and 1.3 (Heml/fed.) in the first and second season, respectively. Nitrogen uptake (\%) by wheat at booting stage increased by decreasing distance from drain line from $L / 2$ to $L / 4$ and the increase was significant in the second season with high wheat yield.

Data also indicated that wheat grain and straw yield significantly increased with increasing applied nitrogen rate up to $100 \mathrm{~kg} \mathrm{~N} / \mathrm{fed}$. in both studied seasons. Weight of 1000 grain $(\mathrm{gm})$ and nitrogen uptake \% at booting stage responsed to the increment of nitrogen applied rate with a significant increase at the highest nitrogen rate $(100 \mathrm{~kg} \mathrm{~N} / \mathrm{fed}$.).

Results also showed that the interaction between distance from drain line and $\mathrm{N}$-fertilization rate on wheat yield characteristics was positive. The highest values of wheat yield characteristics and $\mathrm{N}$-uptake (\%) were obtained at $L / 4$ distance from drain line and $100 \mathrm{~kg} \mathrm{~N} / \mathrm{fed}$. applied rate. In the first season, the effect of interaction on increasing wheat characteristics was significant at a rate of $100 \mathrm{~kg}$ $\mathrm{N} /$ fed., where it significantly increased 1000 grain weight (gm) and wheat grain yield (ardab/fed.) in the second season at the same nitrogen applied rate.

The obtained results revealed also that $20 \mathrm{~m}$ spacing in clay soils is not the proper but may be economic. In addition, distance from drain line must be taken into consideration when distributing fertilizer treatments and their replicates in fertilization experiments to obtain reliable results.

Keywords:Nitrogen rates, drain line distance, clay soil.

\section{INTRODUCTION}

Many factors are limiting crop production such as drainage and nitrogen fertilization. Tile drainage has been increased soil productivity by facing the twin problems of water logging and soil salinity and subsequently offer the suitable environments for plant growth and also for human being (Osterbaan, 1994 and Abd El-Khalek, 2000). Ramadan et al. (1994) indicated that, the $10 \mathrm{~m}$ drain spacing had the lower values of bulk density and penetrability and the higher ones of porosity and infiltration rate than the $20 \mathrm{~m}$ and $40 \mathrm{~m}$, respectively. 
The tile drainage also causes very important changes in nutrients movement which make these nutrients more available for plant growth (Balasubramanian and Chair, 1983 and Belayneh, 1986). On the other hand, nitrogen is the most important nutrients required for all plants to obtain improving yield and its quality (Rees et al., 1996). Several researchers have studied the effect of nitrogen fertilizer at the different rates on growth and yield of wheat (Zebarth and Sheard, 1992; Ashok et al., 1995; Rees et al., 1996; Kara and Agdag, 1996 and Abd El-Monem, 1996). The previous studies for nitrogen fertilizer, reported that grain, straw yields and 1000 grains weight were significantly increased with increasing nitrogen application rate.

The effect of nitrogen fertilization on nitrogen uptake by wheat was studied by several workers (Faizy et al., 1986; Rees et al., 1996 and Sharma and Komal, 1998). Nitrogen uptake is a parameter expresses the value resulted form increasing both dry matter production and nitrogen concentration in any plant part. Increasing nitrogen application rates significantly increased $\mathrm{N}$-concentration and uptake in grain and straw at harvest stage. Also, it significantly increased the $\mathrm{N}$-concentration and its uptake in whole plant of wheat at booting stage in the two seasons (ElNaggar, 1999).

In fertilization experiments, researches usually distribute the fertilizer treatments randomly in soil despite of its position between tile drains. The objectives of the present work were to study the effect of distance form drain line on N-uptake and yield of wheat (Giza 168 variety) under different rates of applied $\mathrm{N}$-fertilizer.

\section{MATERIALS AND METHODS}

Two field experiments were carried out at Sakha Agricultural Research Station, Kafr El-Sheikh Governorate, at north Delta. The field is provided with tile drains network spaced at $20 \mathrm{~m}$ with $1.2 \mathrm{~m}$ depth. Wheat (Giza 168 variety) was planted in 2003/2004 and 2004/2005 seasons. All plots received total of $100 \mathrm{~kg}$ Ca-superphosphate/fed. during tillage operations. Nitrogen fertilizer was used in the form of urea $(46.5 \%)$ and broadcasted at a rate of 50,75 and $100 \mathrm{~kg} \mathrm{~N} / \mathrm{fed}$. (equivalent to 66.67, 100.00 and $133.33 \%$ of the recommended rate) in two equal doses before the first and second irrigation. The aforementioned applied $\mathrm{N}$-rates were disturbed at $L / 4$ and $L / 2$ distance of drain lines in both seasons. The different agricultural practices were done as recommended through the two growing seasons. Prior to tillage operation, the soil samples were collected in $30 \mathrm{~cm}$ increments to $120 \mathrm{~cm}$ depth for chemical and physical analysis according to Klute (1986) and Page (1982). The soil proprieties are shown in Table (1).

To monitor water table fluctuations, observation wells were installed midway between drains at $1 / 2$ and $1 / 4$ distances form tile drain as recommended by Dieleman and Trafford (1976). Whole wheat plant samples at booting stage (after addition of the two nitrogen doses) were taken, dried at $70^{\circ} \mathrm{C}$, grounded with a mill and its total nitrogen content was determined using Kjeldahl digestion (Cottenie et al., 1982). 
The experimental design was a randomized complete block with three replicates, two distances from drain line and three nitrogen fertilization
rates.

Table (1): Physical and chemical properties of the soil samples before wheat planting (2003/2004 and 2004/2005 seasons).

\begin{tabular}{|c|c|c|c|c|c|c|c|c|c|c|}
\hline Soil & Particle size distribution & Texture & $\mathrm{EC}$ & $\mathrm{OM}$ & $\mathrm{CaCO}_{3}$ & \multicolumn{2}{|c|}{ Available N, P, K (mg/kg soil) } \\
\hline $\begin{array}{c}\text { depth } \\
\text { (cm.) }\end{array}$ & $\begin{array}{c}\text { Sand } \\
\%\end{array}$ & $\begin{array}{c}\text { Silt } \\
\%\end{array}$ & $\begin{array}{c}\text { Clay } \\
\%\end{array}$ & class & (dS/m) & $\%$ & $\%$ & $\mathrm{~N}$ & $\mathbf{P}$ & $\mathrm{K}$ \\
\hline \multicolumn{10}{|c|}{ Season 2003/2004 } \\
\hline $0-30$ & 21.42 & 29.42 & 49.16 & Clayey & 1.40 & 0.92 & 3.22 & 46.16 & 5.50 & 273.0 \\
$30-60$ & 20.55 & 27.41 & 52.04 & Clayey & 1.10 & 0.84 & 3.61 & 38.08 & 5.00 & 224.3 \\
$60-90$ & 21.12 & 27.14 & 51.74 & Clayey & 1.40 & 0.61 & 2.71 & 44.80 & 3.50 & 199.0 \\
$90-120$ & 15.95 & 29.48 & 54.62 & Clayey & 1.98 & 0.38 & 1.81 & 34.88 & 3.50 & 146.3 \\
\hline \multicolumn{10}{|c|}{ Season 2004/2005 } \\
\hline $0-30$ & 27.40 & 22.34 & 49.66 & Clayey & 1.58 & 1.52 & 3.81 & 52.64 & 6.50 & 282.8 \\
$30-60$ & 29.27 & 24.76 & 45.97 & Clayey & 0.98 & 1.10 & 3.68 & 44.80 & 4.50 & 253.5 \\
$60-90$ & 30.10 & 28.25 & 41.65 & Clayey & 1.37 & 0.80 & 2.69 & 48.16 & 4.30 & 195.0 \\
$90-120$ & 30.92 & 29.06 & 40.02 & Clayey & 2.32 & 0.65 & 2.06 & 36.15 & 3.90 & 165.3 \\
\hline
\end{tabular}

\section{RESULTS AND DISCUSSION}

\section{Rate of water table draw-down:}

As shown in Fig. (1), the calculated rate of draw-down in both studied seasons was decreased with increasing time after irrigation. The highest values of draw-down were found after one day from irrigation. While the lowest values were found before the next irrigation. The rate of water table draw-down near the drains $(L / 4)$ was higher than that in midway between drains $(L / 2)$. This may be due to the improved drainage near the drains than midway between it which, in return, gave the top soil chance to dry and permitted for shrinkage and formation of water passage ways and allowed a rather easier movement of water into drain pipes. Similar results were obtained by Antar (2005).

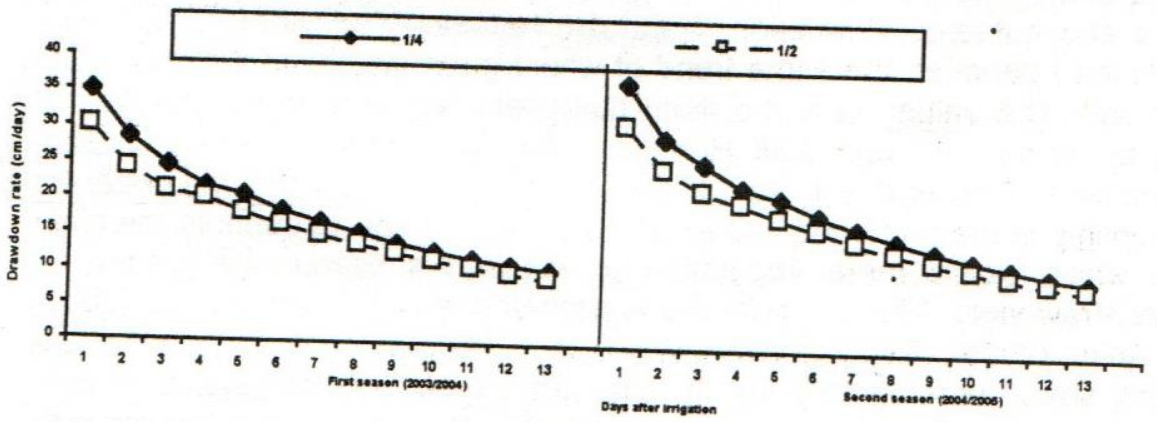

Fig. (1): Average water draw-down rate at 1/4 and 1/2 distance from tile drain under wheat crop in 2003/2004 and 2004/2005 seasons.

\section{Effect of distance from drain line on wheat yield
characteristics:}

Data in Table (2) showed that there was a significant increase in the weight of 1000 grains with decreasing the distances form drain line. The mean values in the first season were 38.81 and $40.18(\mathrm{gm})$, while in the second one they were 39.56 and $40.72(\mathrm{gm})$ for the distances at $L / 2$ and $L / 4$ 
spacing between tile drains, respectively. The increment in 1000 grains weight with decreasing the distances from drain line may be discussed on the base that drainage near the drain line at $1 / 4$ distance from the drain line is better than that at midway between drain (L/2), causing improving water-air balance in the root zone, increasing soil micro-organisms activity, developing better structure and increasing the availability of nutrients for plant roots. These results are in agreement with those obtained by El-Gohary et al. (1989).

Table (2): Effect of spacings from drain line on yield components and $\mathrm{N}$-uptake at booting stage of wheat crop.

\begin{tabular}{|c|c|c|c|c|}
\hline Treatment & $\begin{array}{l}\text { Grains/yield } \\
\text { (ardab/fed.) }\end{array}$ & $\begin{array}{l}\text { Straw yield } \\
\text { (Heml/fed.) }\end{array}$ & $\begin{array}{c}1000 \text { grain weight } \\
\text { (g) }\end{array}$ & $\begin{array}{c}\text { N-upta'e } \\
\%\end{array}$ \\
\hline \multicolumn{5}{|c|}{ Season $2003 / 2004$} \\
\hline (1) $L / 2$ & 17.29 & $\frac{1}{17.35}$ & 38.81 & 0.758 \\
\hline (2) $L / 4$ & 18.72 & 19.04 & 40.18 & 0.775 \\
\hline F-test 0.05 & $* *$ & $\star \star *$ & $* *$ & N.S \\
\hline L.S.D. 0.05 & 0.797 & 0.978 & 0.827 & - \\
\hline \multicolumn{5}{|c|}{ Season 2004/2005 } \\
\hline (1) $L / 2$ & 19.83 & 20.53 & 39.56 & 0.829 \\
\hline (2) $U / 4$ & 21.72 & 21.88 & 40.72 & 0.852 \\
\hline F-test 0.05 & $* *$ & $* *$ & $* \star$ & * \\
\hline L.S.D. 0.05 & 1.345 & 1.071 & 0.825 & 0.022 \\
\hline
\end{tabular}

(1) $L / 2=1 / 2$ distance from tile drain

(2) $L / 4=1 / 4$ distance from tile drain

Results in Table (2) showed also that there was a significant increase in wheat grain yield with the decrease in the distance from drain line. The values near the drain line $(L / 4)$ were higher by about 1.43 and 1.89 ardab/fed. than that far from it $(L / 2)$, for the first and second season, respectively. Similar results were found by Antar (2005). He attributed that to the favourable soil physical and chemical conditions such as water-air relationships in the root zone, root penetration which leads to more water intake and nutrients absorption. Data also revealed that wheat straw yield (Heml/fed.) behaved the same trend of wheat grain yield with distance from drain line. The values near the drain $(L / 4)$ were higher than that far from it $(L / 2)$ by about 1.69 and $1.35 \mathrm{Heml} / \mathrm{fed}$., for the first and second season, respectively. This is due to the effect of drainage on conditioning water-air relationship in the root zone and its effect on mobility of nutrients to the plant roots which cause more vegetative growth and subsequently produce a higher straw yield. These results are in accordance with Ibrahim et al. (2003) and Antar (2005). Results also showed that, $\mathrm{N}$-ujptake by wheat plants at booting stage increased as the distance from drain line decreased in both studied seasons. These increases were significant in the second season with high yield, Table (2). The increment in $\mathrm{N}$-uptake near tile drain than far from it may be ascribed to increasing wheat root biomass as a result of favorable soil physical properties such as soil structure, aeration due to the relatively higher rate of water table drawdown (Fig. 1), near tiles than that far from it.

3.Effect of $\mathrm{N}$ applied rate on wheat yield characteristics:

Results in Table (3) showed that 1000 grain weight (gm) significantly increased as the nitrogen applied rates increased in the two studied seasons up to $100 \mathrm{~kg} \mathrm{~N} / \mathrm{fed}$. The mean values of 1000 grain weight, for the two 
seasons, were 38.36 and $41.57 \mathrm{gm}$ for 50 and $100 \mathrm{~kg} \mathrm{~N} / \mathrm{fed}$., respectively. The increment in 1000 grains weight as a result of increasing $\mathrm{N}$-fertilization rate may be due to the role of nitrogen in increasing the amount of metabolites liable to transport to the grains, El-Yamany (1994), Mostafa et al. (1997) and Abd El-Khalek (2000).

Table (3): Effect of $\mathrm{N}$-rates on yield, yield components and $\mathrm{N}$-uptake \% at booting stage of wheat crop.

\begin{tabular}{|c|c|c|c|c|}
\hline $\begin{array}{c}\text { N-rate } \\
\text { (kg N/fed) }\end{array}$ & $\begin{array}{c}\text { Grain yield, } \\
\text { (ardab/fed.) }\end{array}$ & $\begin{array}{c}\text { Straw yield, } \\
\text { (Heml/fed.) }\end{array}$ & $\begin{array}{c}\text { 1000 grain weight } \\
\text { (gm) }\end{array}$ & $\begin{array}{c}\text { N-uptake } \\
\%\end{array}$ \\
\hline \multicolumn{5}{|c|}{ Season 2003/2004 } \\
\hline 50 & $16.27 \mathrm{c}$ & $16.66 \mathrm{c}$ & $37.94 \mathrm{~b}$ & $0.709 \mathrm{~b}$ \\
75 & $17.39 \mathrm{~b}$ & $18.89 \mathrm{~b}$ & $39.12 \mathrm{~b}$ & $0.733 \mathrm{~b}$ \\
100 & $20.35 \mathrm{a}$ & $20.03 \mathrm{a}$ & $41.13 \mathrm{a}$ & $0.859 \mathrm{a}$ \\
\hline \multicolumn{5}{|c|}{} \\
\hline 50 & $18.67 \mathrm{c}$ & $18.78 \mathrm{c}$ & Season 2004/2005 \\
\hline 75 & $20.67 \mathrm{~b}$ & $21.03 \mathrm{~b}$ & $38.775 \mathrm{~b}$ & $0.792 \mathrm{~b}$ \\
100 & $22.99 \mathrm{a}$ & $23.83 \mathrm{a}$ & $42.010 \mathrm{a}$ & $0.859 \mathrm{a}$ \\
\hline
\end{tabular}

Data in Table (3) revealed also that wheat grain yield (ardab/fed.) significantly increased as the nitrogen applied rate increased up to $100 \mathrm{~kg}$ $\mathrm{N} / \mathrm{fed}$. The mean values of wheat grain yield varied from 16.27 to 20.35 and from 18.67 to 22.99 ardab/fed. in the first and second season, respectively. $\mathrm{N}$-fertilization rates of 75 and $100 \mathrm{~kg} \mathrm{~N} / \mathrm{fed}$. were higher than $50 \mathrm{~kg} \mathrm{~N} / \mathrm{fed}$. in the first seasons by about 1.12 and 4.08 ardab/fed., while they were 2.0 and $4.32 \mathrm{ardab} / \mathrm{fed}$. in the second season, respectively. The increment in grain yield due to nitrogen fertilizer may be explained by the increase in most correlated yield components, which increase the final yield. Results also showed a significant increase in straw yield as a result of increase nitrogen application rate up to $100 \mathrm{~kg} \mathrm{~N} / \mathrm{fed}$. The increment in straw yield/fed. may be attributed to the beneficial effect of added available nitrogen on wheat vegetative growth through the increase in total nitrogen uptake. These results are in harmony with those obtained by Ibrahim (1998) Abd El-Khalek (2000).

As to $\mathrm{N}$-uptake, data showed that wheat plants (Giza 168 variety) at booting stage responded to the increase in nitrogen applied rates up to 100 $\mathrm{kg} \mathrm{N} / \mathrm{fed}$. in both seasons. The increases in $\mathrm{N}$-uptake with increasing the added $\mathrm{N}$-fertilizer were significant at $100 \mathrm{~kg} \mathrm{~N} / \mathrm{fed}$. in the first season and 75 , $100 \mathrm{~kg} \mathrm{~N} / \mathrm{fed}$. in the second season. Sarhan and Abd El-Salam (1999), ElNaggar (1999) and Abd El-Khalek (2000) noticed that nitrogen fertilization increased the capability of wheat plants to absorb more nutrients. This might be attributed firstly to the increases in the root surface and enrichment of soil solution with nitrogen which reflects its influence on $\mathrm{N}$-concentration in plant tissues. This raising in $\mathrm{N} \%$ in plant tissues may be contributed in building up metabolites and subsequently increasing dry matter production up to full growth stage and then increases nutrients uptake by wheat plant.

4. Interactions between $\mathrm{N}$-applied rates and distances from drain line:

- Data in Table (4) showed that, weight of 1000 grains, grain yield, straw yield and $\mathrm{N}$-uptake \% by wheat plants at booting stage increased with increasing $\mathrm{N}$-fertilization rates up to $100 \mathrm{~kg} \mathrm{~N} / \mathrm{fed}$. and decreasing the distance from drain line. 
Ramadam. S.A. et al.

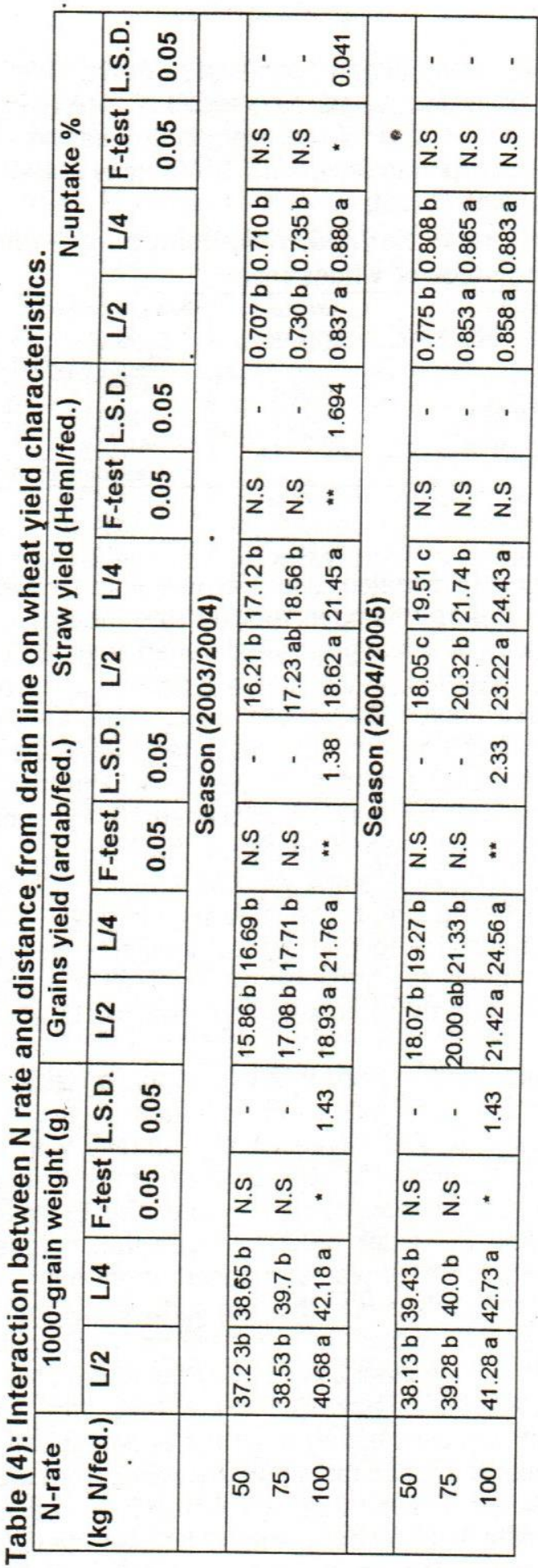




\section{J. Agric. Sci. Mansoura Univ., 31 (4), April, 2006}

The increases of 1000 grain (gm) and grain yield (ardab/fed.) were significant at $100 \mathrm{~kg} \mathrm{~N} / \mathrm{fed}$. applied rate and decreasing distance from drain line from $L / 2$ to $L / 4$ in both studied seasons. Data also cleared that wheat straw yield (Heml/fed.) and $\mathrm{N}$-uptake \% significantly increased at $100 \mathrm{~kg} \mathrm{~N} / \mathrm{fed}$. and $\mathrm{L} / 4$ distance from drain line in 2003/2004 season, while the increases of such values in 2004/2005 season were insignificant.

Finally, the obtained data in this study revealed that $20 \mathrm{~m}$ spacing from tile drains in the area investigated is not the optimum, but may be economic. On the other hand, to obtain reliable results in fertilization experiments, the space from drain line must be taken into consideration when distributing fertilizer treatments and its replicates in the fields provided with tile drain networks.

\section{REFERENCES}

Abd El-Khalek, M.I.(2000). Nitrogen loss and uptake as affected by nitrogen application and tile drainage. Ph.D. Thesis, Fac. of Agric., Mansoura University, Egypt.

Abd El-Monem, M.A.S. (1996). Nitrogen utilization by spring wheat as estimated by $\mathrm{N}^{15}$ technique under irrigation in Egypt. J. Agric. Sci., Mansoura Univ., 21(7): 2455-2461.

Antar, A.S. (2005). Movement of some nitrogen forms, atrazine and malathion in clay soil as affected by drain spacings. Ph.D. Thesis,

Fac. of Agric., Tanta University, Egypt.

Ashok, K.; D.K. Sharma; H.C. Sharma and A. Kumar (1995). Nitrogen uptake, recovery and $\mathrm{N}$-use efficiency in wheat as influenced by nitrogen and irrigation levels in semi-reclaimed sodic soils. Indian Journal of Agronomy. 40(2): 198-203.

Balasubramanian, G. and A.V. Chair (1983). Effect of irrigation scheduling on grain yield and nitrogen use efficiency of irrigated wheat at Kadawa and Bakura, Northern Nigeria. Fertilizer-Research. 4(3): 201210.

Belayneh, H. (1986). The effect of drainage systems, drainage spacing and fertilizer on seed yield and other characters of wheat, teff and chickpea on heavy clay soils of Ghinchi. Ethiopian-Journal of Agricultural. Sciences. 8(2): 85-94.

Cottenie, A.; M. Verloo; L. Mjkiekens: G. Velghe and R. Comertynck (1982). Chemical analysis of plant and soil. Lab. Anal. And Agrochem. State Univ., Gent., Belgium, Chapter 2 and 3, pp. 14-54.

Dieleman, P.J. and B.D. Trafford (1976). Drainage testing, irrigation and drainage paper No. 28. FAO, Rome.

El-Gohary, S.A.; A.A. El-Leithi and H.H. Ali (1989). Effect of tile drainage and nitrogen fertilization on some soil properties and yield as well as

- components of wheat in heavy clay soils. J. Agric., Tanta Univ., 15(3): 569-582.

El-Naggar, E.M.A. (1999). Efficiency of bio and chemical fertilization on wheat. Ph.D. Thesis, Fac. of Agric., Mansoura Univ., Egypt. 
El-Yamany, M.S. (1994). Study of the efficiency of some fertilizer treatments on wheat under different irrigation conditions. Ph.D. Thesis Fac. of Agric. Ain Shams Univ., Egypt.

Faizy, S.E.A.; M.S. Shams; M.M. Rizk and A.M. Hamissa (1986). Effect of the rate and time of urea application on yield and yield compositions of wheat plants. J. Agric. Res., Tanta Univ., 12(4): 1205-1216.

Ibrahim, M.M. (1998). Effect of herbicides and biofertilization on growth and yield of wheat under different nitrogen fertilizer levels. Ph.D. Thesis, Fac. of Agric., Mansoura Univ., Egypt.

Ibrahim, S.M.; S.A. Gaheen; M.A. Koriem and A.S. Anter (2003). Atrazine and nitrate transport through a clay soil into subsurface tile drains of different spacings. J. Agric. Res. Tanta Univ., 29(2): 335-353.

Kara, S.M. and M.L. Agdag (1996). Effect of different nitrogen fertilizer rates on grain yield of bread wheat cv. Marmara 86 in Samsun and Dinop. Ondodkuzmayis Universities, Ziraat Faultesi Degisi, Turkey. 11(1): 93-104.

Klute (1986). Water retention laboratory methods. In: A. Klute (ed.) Methods of Soil Analysis, Part $1,2^{\text {nd }}$ ed. Agron. Monogr. 9. A.S.A. Madison, WI. USA, p. 635-.

Mostafa, M.A.; A. Helmy and M.A. Salem (1997). Effect of nitrogen fertilization on yield and yield components of wheat under new land environment. J. Agric. Sci. Mansoura Univ., 22(1): 1-11.

Osterbaan, R.J. (1994). Agricultural drainage criteria. In: drainage principles and applications Publ. 16. Second edition. (Edited by Ritzema, H. P.) ILRI, Wagningen, the Netherlands.

Page, A.L. (E.D) (1982). Methods of Soil Analysis, Part 2. Chemical and Microbiological Properties ( $\left.2^{\text {nd }} E d.\right)$. American Society of Agronomy. In Soil Sci. of Amer. Inc. Madison Wisconsin. USA.

Ramadan, S.A.; S.A. El-Gohary and A.A. El-Leithi (1994). Influence of tile drainage spacing under rice cultivation on some chemical and physical properties of heavy clay soil. J. Agric. Sci. Mansoura Univ. 19(9): 3119-3133.

Rees, R.M.; M. Roelcke; X.O. Wang and J. Richter (1996). the effect of fertilizer placement on nitrogen uptake and yield of what and maize in Chinese losses soils. Nutrient Cycling in agroecosystems. 47(1): 8191.

Sarhan, S.H. and H.Z. Abd El-Salam (1999). Effect of soil salinity, nitrogen fertilization and their interaction on wheat plant. J. Agric. Sci. Mansoura Univ., 24(4): 2071-2075.

Sharma, D.P. and S. Komal (1998). Effect of subsurface drainage system on some physicochemical proprieties and wheat yield in waterlogged saline soil. Journal of the Indian Society of Soil Science. 46(2): 284288.

Zebarth, B.J. and R.W. Sheard (1992). Influence of rate and timing of nitrogen fertilization on yield and quality of hard red winter wheat in Ontario. soils and Fertilizer. 56: 1. 


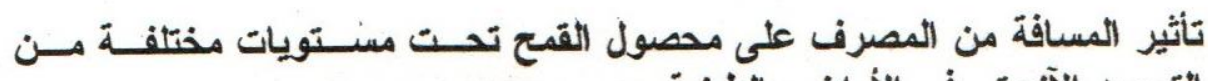

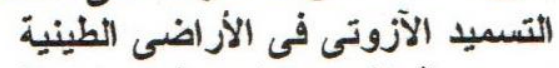

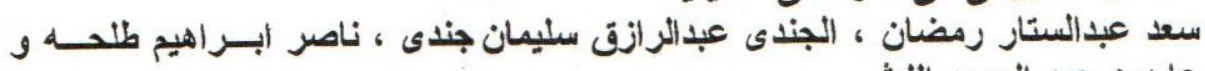
عابدين عبد الحميد الليثئ ردمان

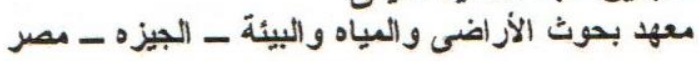

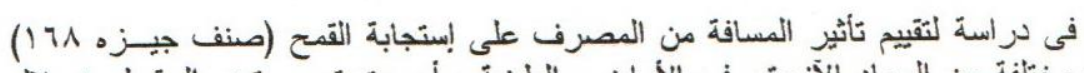

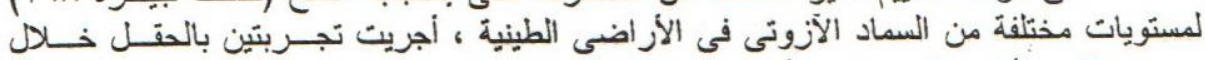

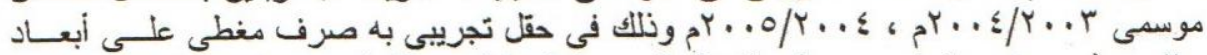

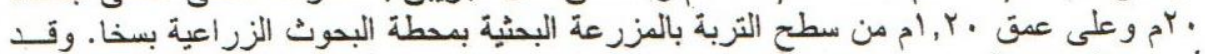

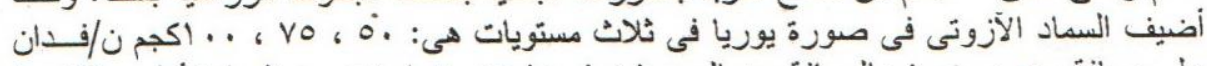

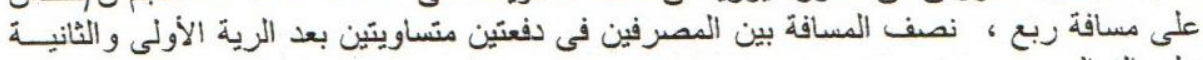

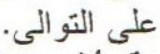

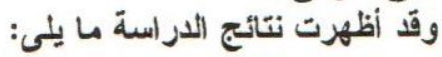

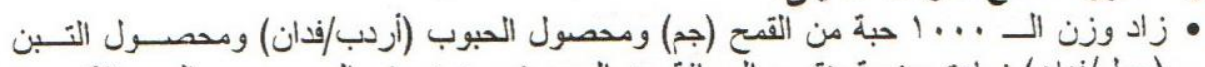

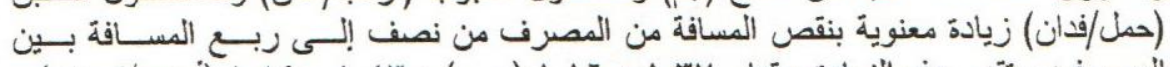

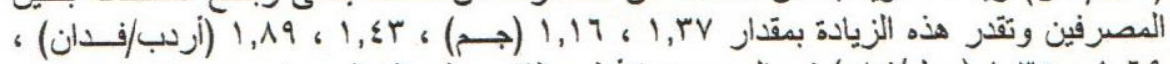

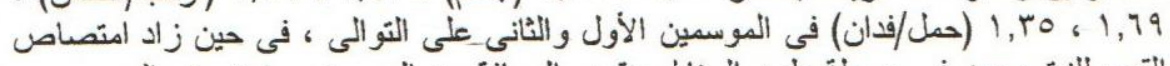

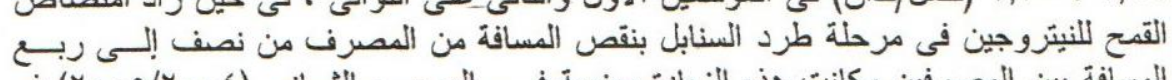

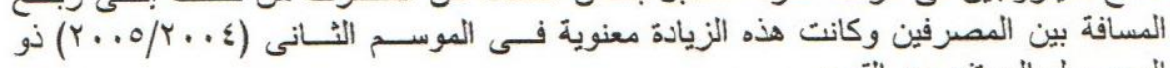

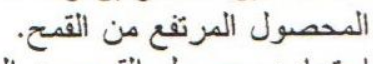

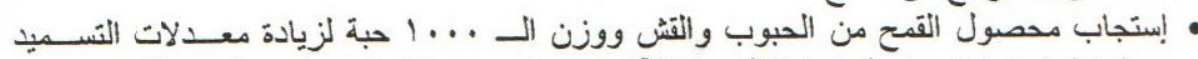

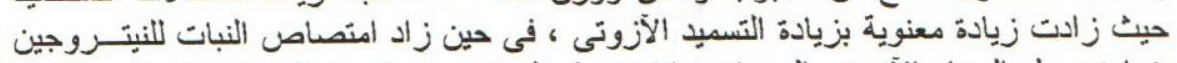

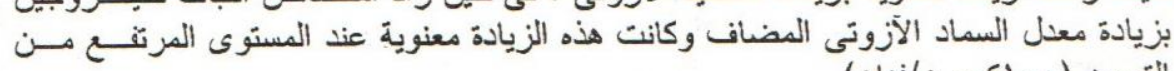

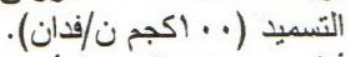

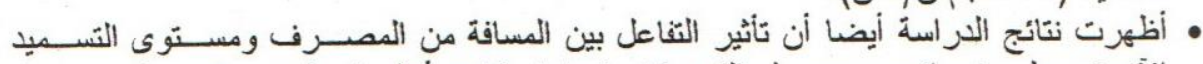

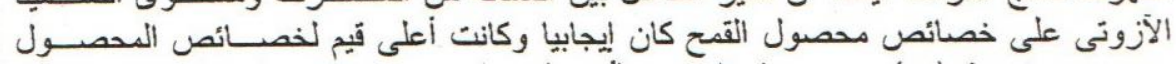

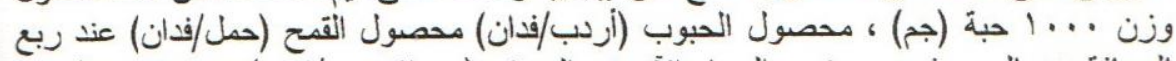

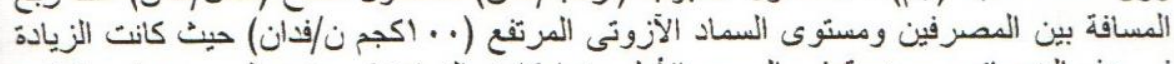

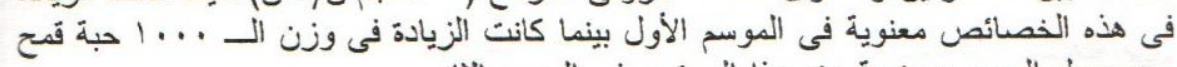

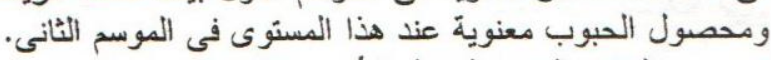

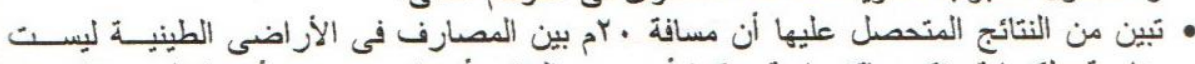

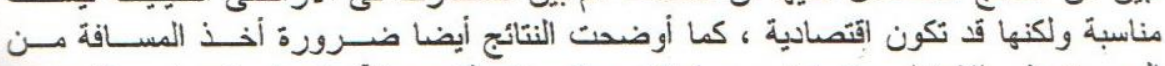

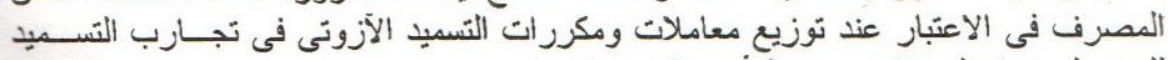
للحصول منها على نتائج مرضية أو مونيع معثوت بهات 